\title{
Renewable Energy and Disaster-Resistant Buildings
}

\author{
Author \\ Young, William \\ Presented at: \\ ISES/Solar World Congress 2005, \\ Orlando, Florida USA, \\ August 8-11, 2005 \\ Publication Number \\ FSEC-PF-385-05

\section{Copyright} \\ Copyright (C) Florida Solar Energy Center/University of Central Florida \\ 1679 Clearlake Road, Cocoa, Florida 32922, USA \\ (321) 638-1000 \\ All rights reserved.
}

\section{Disclaimer}

The Florida Solar Energy Center/University of Central Florida nor any agency thereof, nor any of their employees, makes any warranty, express or implied, or assumes any legal liability or responsibility for the accuracy, completeness, or usefulness of any information, apparatus, product, or process disclosed, or represents that its use would not infringe privately owned rights. Reference herein to any specific commercial product, process, or service by trade name, trademark, manufacturer, or otherwise does not necessarily constitute or imply its endorsement, recommendation, or favoring by the Florida Solar Energy Center/University of Central Florida or any agency thereof. The views and opinions of authors expressed herein do not necessarily state or reflect those of the Florida Solar Energy Center/University of Central Florida or any agency thereof. 


\title{
RENEWABLE ENERGY AND DISASTER-RESISTANT BUILDINGS
}

\author{
Abstract Number: 1545 and 76044 \\ ISES/Solar World Congress 2005, \\ Orlando, Florida USA, \\ August 8-11, 2005 \\ William Young, Jr. \\ Florida Solar Energy Center \\ 1679 Clearlake Road \\ Cocoa, Florida 32922 \\ Email: young@fsec.ucf.edu
}

\begin{abstract}
$\underline{\text { ABSTRACT }}$
Hurricanes, floods, tornados and earthquakes create natural disasters that can destroy homes, businesses and the natural environment. Such disasters can happen with little or no warning, leaving hundreds or even thousands of people without medical services, potable water, sanitation, communications and electrical services for up to several weeks. The 2004 hurricane season ravaged the State of Florida, U.S.A., with four major hurricanes within a 6week timeframe. Over nine million people evacuated their homes and damage to property was extensive.
\end{abstract}

One proactive strategy to minimize this type of destruction and disruption to lives is the implementation of disasterresistant buildings that are functional and operational. This approach uses the best energy-efficient buildings, fortified to the latest codes, and incorporates renewable energy systems. Businesses, government facilities and homes benefit from using photovoltaics to power critical items. This concept is a mitigation tool to reduce damage and cost of the destructive forces of hurricanes and other disasters. This past season's experience showed that buildings designed and built to the latest standards with photovoltaic and solar thermal systems survived with little damage and continued to perform after the storm passed. Even following a disaster, energy conservation and use of renewables promotes energy assurance while allowing occupants to maintain some resemblance of a normal life.

\section{INTRODUCTION}

Dependence on energy characterizes our daily lives through the use of computers, communications products, refrigerators, televisions, water heaters and lighting. A loss of power can disrupt our daily routine and at worst, our health and financial welfare. Man-made and natural disasters can destroy homes, businesses and the natural environment. Such disasters can happen with little or no warning, leaving hundreds or even thousands of people without medical services, potable water, sanitation, communications and electrical services for up to several weeks.

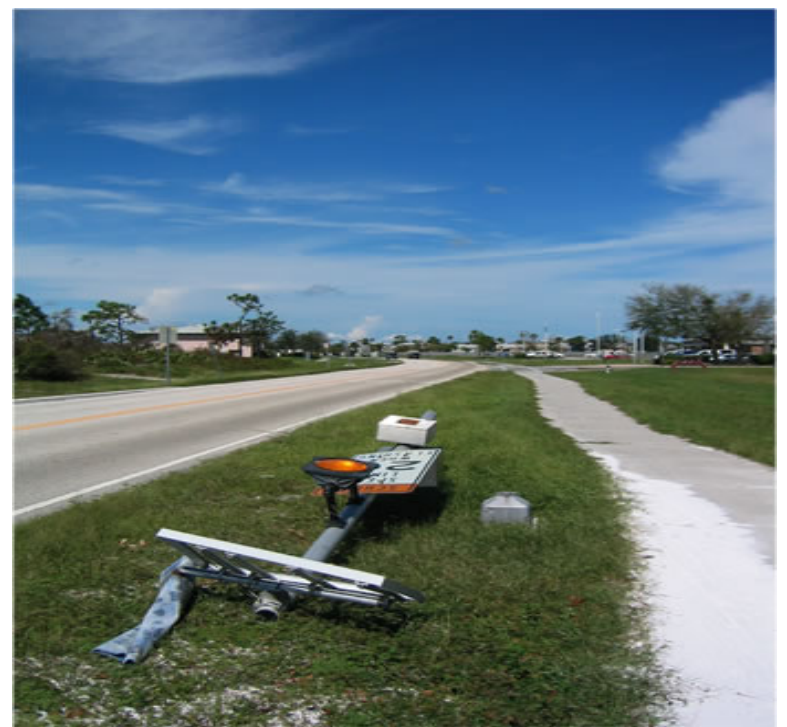

Fig. 1: Jeanne at Palm Bay Elementary (PV signal).

In 2004, the State of Florida, U.S.A., was ravaged by four major hurricanes within a 6-week timeframe. The biggest reported series of evacuations due to natural disasters occurred, requiring 9 million people to seek shelter somewhere other than their home to prevent injury and protect lives. Nearly all of the geographic area of the state was affected in some way. Hurricanes Charlie, Frances, Ivan 
and Jeanne did major damaged to 40,000 buildings and destroyed 25,000 homes, leaving over 8 million people without electricity.

The loss of utility service especially affects shelters, medical facilities, pumping stations, fire stations and police stations needed in response and recovery. Emergency organizations, businesses and homeowners are hampered in the recovery process by the loss of power. In 1979, the United States government created the Federal Emergency Management Agency (FEMA) to provide guidance and assistance to State and local government in disaster response and recovery. The program developed a close working partnership between all levels of government (federal, state, county, and local) and the private sector (business, industry, voluntary organizations, and general pubic) to manage disasters. Local government agencies prepare and maintain a Comprehensive Emergency Management Plan (CEMP) that specifies how citizens and property will be protected in a potential disaster. The CEMP describes the levels of responsibility, resources, operating procedures and actions to be taken during preparedness, response, recovery, and mitigation.

The Florida State Legislature established statutes defining State, County Government and School Districts’ responsibility for safety of life and property during a declared emergency. Public schools are the primary source of public shelter during emergencies, currently accounting for about 93 percent of statewide hurricane shelter space. International, national and local building codes were enacted to ensure safe buildings, thereby reducing deaths, injuries and property damage. In 1992, Hurricane Andrew changed our perspective on building design and building codes were updated to address new structural performance standards and sustained winds over $120 \mathrm{mph}$.

\section{2...ENERGY SECURITY AND UTILITIES}

The energy supply industry has created a huge infrastructure to distribute reliable and cost effective power throughout the U.S.A. Most buildings and homes in the States are powered by utility companies that utilize a complex electric grid or pipeline to distribute energy across a wide geographic area. The utility industry is vulnerable to power outages due to systems failures caused by weather, physical failure, human error or market-based instability and intentional disruption of a power system (sabotage). Due to the vast size and complexity of the system, it is difficult to protect all utility facilities from possible attack or failure. Any type of power outage temporarily highlights the degree of importance of electricity in our lives, whether caused by a disaster or a minor weather-related event.
Utilities and regulators are developing “resilient” network architecture in order to provide energy assurance to keeping operating in spite of multiple disruptive events. Several factors effect energy assurance, such as proximity to load, fuel availability, facility protection, facility size, geographic location and vulnerability of technology. Disasters have varying impacts on utility resources. For example, a hurricane can tumble electric power lines but not impact natural gas lines underground. There are options to improve energy security of the network, such as energy efficient practices, distributing energy sources and using renewable resources. Efficiency and conservation reduces the need for new generation. Use of distributed generation can provide multiple sources of energy and promote reliability. By using renewable energy resources, sustainability and energy security are enhanced.

The future poses a critical problem: as the population grows, so grows the load. This increase in demand will significantly increase energy consumption and a corresponding need to greatly increase generating capacity. The American public is so highly dependent on utility providers to meet energy needs that it is now the right and the responsibility of each citizen to become aware of energy security issues and to accept a shared accountability for meeting personal and collective energy needs. Just as utilities and regulators seek to improve energy system security, so too should the consumer implement the same measures to improve personal energy security. Consumers willing to take responsibility for generating part or all of their energy needs must learn to understand the energy requirements of their many appliances and electrical devices, whether connected to the grid or their own energy systems. Consumers should become "utility owners and operators" to enhance energy security by reducing overall and peak loads.

\section{DISASTER-RESISTANT BUILDINGS}

In the late 1990s, FEMA began a new approach to mitigation by promoting disaster-resistant buildings for disaster resistant communities. A disaster-resistant building is built beyond conventional building methods and codes. This building method will likely cost more at the time of construction, but is positioned to deliver priceless life and property saving during and after a disaster. As an example, a disaster-resistant building would have extra nails in the roof decking, water barriers along the roof joints and wildfire buffers around the perimeter. The Federal Alliance for Safe Homes created the Blueprint for Safety program to provide a comprehensive set of disaster-resistant building techniques for protecting both new and existing homes from hurricanes, tornadoes, flooding and wildfires. The Institute for Business and Home safety created the Fortified Builders' Guide to provide techniques for a higher level of 
protection against disasters. These and other programs are available to provide guidance to structurally enhance a building to save life and reduce property damage. Preparedness and mitigation to reduce damage and losses reduces the amount of response and recovery effort potentially needed.

Following a disaster, if the building is still standing, the building design should provide sustainable operational use. The U.S. Department of Energy, with support from the Florida Solar Energy Center (FSEC), added the concept of building functionality and operational capacity to the importance of creating structurally sound and safe buildings. A disaster-resistant building should achieve the lowest energy consumption, applying a variety of possible conservation options. Energy consumption can be minimized to various degrees, with the ultimate being zero energy input from conventional grid utilities. Energy codes need to be changed to promote sustainability; this represents a step beyond minimum energy codes. From an energy security aspect, zero energy buildings would have energy production in close proximity to the load and would provide energy generation equal to consumption.

Renewable energy sources should be used for on-site generation, providing consumers energy assurance in a disaster as well as in normal daily life. If excess generation is produced, it can be redistributed to the utility company or to other loads.

\section{DISTRIBUTED RENEWABLE ENERGY}

Buildings should be disaster-resistant, both structurally and in energy resource requirements. Distributed generation employs multiple sources of energy instead of depending on one large source. Solar systems can be designed and sized as a renewable energy source for varying needs and applications. The Florida Solar Energy Center (FSEC), Sandia National Laboratories and the National Renewable Energy Laboratory have jointly researched the application of photovoltaics (solar electric) in disasters. Photovoltaic (PV) is an environmentally benign, inexhaustible source of electrical energy. Solar-powered equipment requires no fuel, so the length of operation poses no problem when the solar power system is properly designed. Solar energy is a viable, cost effective resource for small portable and stand alone electrical power applications, since it offers lower operating costs than gasoline generators. PV modules are modular, allowing various outputs and the addition of battery storage to a PV system allows 24 hour operation.

PV-powered systems are a natural solution because they can be designed specifically for stand alone operation without utility power as a critical power supply. Some uses, like communications and applications in medical clinics, require quiet, non-polluting operation, which PV is capable of providing. A viable use for PV is to meet the emergency demands in large-scale disasters, where power will be out for long periods of time and survivor support is difficult to provide due to the extensive area destroyed. If structures are still standing after a disaster, PV can serve as a critical power supply or back-up system.

By implementing an integrated approach to addressing critical energy issues, energy production and consumption can be balanced to assure an improved level of energy security and reliability. Distributed energy generation can be applied to building design using renewable energy sources where more than one energy source is used. The use of photovoltaics, solar thermal and wind is needed to ensure sustainability. Solar thermal or hot water systems are cost effective and offset the need to generate electricity to produce hot water. Wind energy may be available at night when solar is not enhances the energy mix. If one or more sources have failed, one or more of the other energy sources could supply the energy needed for the load.

\section{CRITICAL DESIGN}

Consumers, both homeowners and businesses, will benefit from evaluating their energy needs and operational activities. The more energy conserved, the less energy that needs to be produced. This study recommends that renewable energy can be applied at five levels, as shown in the Table 1.

Table 1. Levels of renewable generation in buildings

\begin{tabular}{|l|l|l|l|}
\hline Level & Item & Description & PV Power \\
\hline 1 & $\begin{array}{l}\text { selected } \\
\text { items }\end{array}$ & $\begin{array}{l}\text { outdoor lights, } \\
\text { pump, gate } \\
\text { control }\end{array}$ & $0-200 \mathrm{~W}$ \\
\hline 2 & $\begin{array}{l}\text { critical } \\
\text { items }\end{array}$ & $\begin{array}{l}\text { refrigerator, } \\
\text { light, radio, } \\
\text { register }\end{array}$ & $200-1000 \mathrm{~W}$ \\
\hline 3 & $\begin{array}{l}\text { backup } \\
\text { power }\end{array}$ & $\begin{array}{l}\text { lighting, } \\
\text { kitchen, water } \\
\text { supply, systems }\end{array}$ & $500-2000 \mathrm{~W}$ \\
\hline 4 & $\begin{array}{l}\text { zero } \\
\text { energy }\end{array}$ & $\begin{array}{l}\text { production } \\
\text { equals } \\
\text { consumption }\end{array}$ & $2000-20+\mathrm{kW}$ \\
\hline 5 & producer & $\begin{array}{l}\text { net generator } \\
\text { beyond } \\
\text { consumption }\end{array}$ & $10-100+\mathrm{kW}$ \\
\hline
\end{tabular}

The first level of renewable generation could be a solar outdoor light in the drive way or other stand-alone device. The second level is geared to power critical energy needs in the home or commercial building to ensure needed power is available to maintain key operations. The third level of generation may be to power the garage, kitchen, business 
computer systems, water supply or other major systems to generate as much power as you can afford, but not everything. The fourth level is to power the whole building and produce as much as is consumed. The fifth level is designed to become a power generator for the purpose of redistribution and produces a set amount more than is consumed. Equally important is storage for standalone operation when utility power is out and is usually supplied by batteries with a minimal storage capacity of 1 kw hr.

Levels 2 to 4 would be an advantage in disaster-resistant building design. Levels 2 and 3 use backup power systems that may be stand-alone or grid interactive and fitted to power small electrical and electronic devices or small systems. Of most interest is the critical power supply concept where critical energy needs are identified and incorporated into a power supply design to ensure needed power is available to maintain key operations and functions of a building. As an example, during a power outage, a homeowner will want to have electricity for operating a lamp, a refrigerator and a radio. A business may need a few lights for safety and a cash register to complete sales. Most consumers would consider these items critical to maintaining business operations, building functions and personal lifestyle until utility power is restored. By incorporating even minimal building modifications, such as the addition of a small $1 \mathrm{~kW}$ photovoltaic array, the home or business owner can enhance energy security and realize long-term financial and environmental benefits.

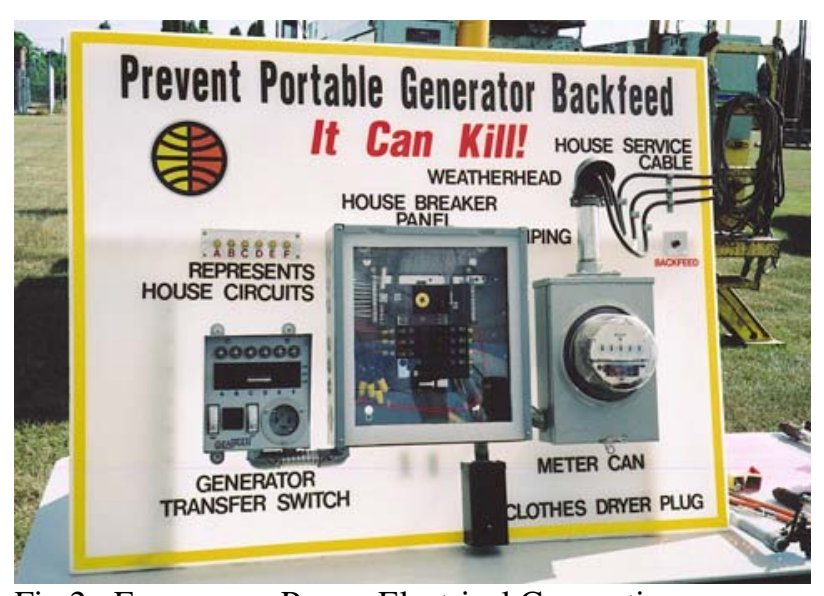

Fig.2: Emergency Power Electrical Connection.

Critical power supply can be achieved by connecting a sub panel to the main power panel of a building through a transfer switch for utility-connection. The sub panel would then be powered by an alternative energy source, such as a PV system, wind, small hydro, solar thermal, microturbines, geothermal or a hydrogen fuel cell generator. Emergency power transfer systems are available at local hardware suppliers. Utilities recommend their use to protect power line workers from backfeed from engine generators as shown in Figure 2. This design concept integrates a distributed energy source to a specific load, assuring energy security. The local utility could power from 1 to 99 percent of the building's energy needs and the building would have critical energy items powered by dual or multiple sources of energy.

\section{6...THE ULTIMATE DISASTER-RESISTANT BUILDING}

Ideally, the truly disaster resistant building would be a zero energy home or building that ensures a high level of energy security. The first step is to conserve energy and reduce the energy load to near zero through passive building design, day lighting, energy efficient appliances, energy management systems, thermal mass, material selection and other practices. U.S. DOE Energy Star and Rebuild America programs provide many guidelines for conservation measures. Conservation means not to do without, but to accomplish a similar or acceptable result using fewer resources. Heating water by a solar thermal water system or pool heating system instead of electricity or other energy source is one example. Another example would be to use wind energy to pump water. Once the load is minimized, renewable energy sources, such as PV, thermal or wind, are applied to match energy needs. Distributing energy resources by applying the right energy source to the right application and employing multiple sources of energy is key.

Energy analyses of various homeowners' needs suggest that a minimum of $2 \mathrm{~kW}$ photovoltaic array with a $2 \mathrm{~kW}$ inverter and battery storage would continuously power most critical needs. The building may have $1 \mathrm{~kW}$ to $20 \mathrm{~kW}$ or more of PV based on design criteria and electrical applications. The PV system can be ground or roof mounted, depending on building design and orientation. The system may be utility interactive with battery back-up to power critical items during power outages. During normal times, the PV system would provide demand side management, offsetting energy consumption. During outages, the system would power critical items required to survive. The energy sources need to be integrated into a comprehensive energy management system to provide a "smart home" energy mix.

\section{DAMAGE ASSESSMENT}

A damage assessment of buildings impacted during the 2004 Atlantic hurricane season found that the homes that originally had solar systems and whose roofs were still intact had a majority of the solar systems still attached. 
Rebuild America and Energy Star homes survived and owners were able to live in their homes during recovery. Some homes only had solar hot water and the owners could at least take hot showers until utility power returned. A few homes had PV, allowing refrigerators and other appliance to operate.

FSEC maintains a database of PV systems deployed through programs they manage. There are 61 buildings with PV systems from 500 to 10,000 watts of PV, of which, 31 have data collection systems that monitor them continuously. All of the systems were operational after the storms hit and only 3 systems reported minor damage. One of the damaged PV systems was from the roof of the building coming off and hitting the PV system causing minor damage to the PV system which was still attached to the building. Only 11 systems were not within the path of the hurricanes.

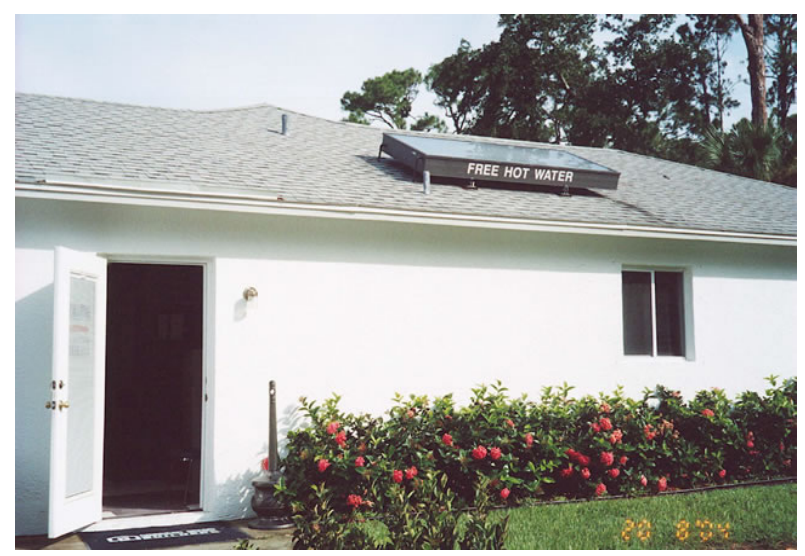

Fig. 3: Charlie at Port Charlotte (thermal system).

Oak Ridge National Laboratory and the Roofing Industry Committee on Weather Issues (RICOWI) conducted a roof damage assessment in Charlotte county after Hurricane Charlie. Seven site evaluation teams assessed 428 buildings and found 14 solar systems of which three were damaged. One PV systems was undamaged. Through contacts with the Florida Solar Energy Industry Association, 28 other PV systems were found as shown in Fig 4 with only four systems damaged.

Studies and experience have shown that PV plays an important role in response, recovery and mitigation in disasters. Portable systems under $1 \mathrm{~kW}$ meets many of the needs of disaster organizations in response efforts, where 1 to $5 \mathrm{~kW}$ systems provide critical stationary power. Small utility-interactive PV systems with battery backup increase the effectiveness of disaster-resistant buildings and ultimately support communities in the power mix for distributed generation. There are inappropriate applications for photovoltaics in response to disasters. Builders, planners, homeowners and Emergency Management personnel need to understand their community's energy needs and photovoltaic technology to make the right application choice.

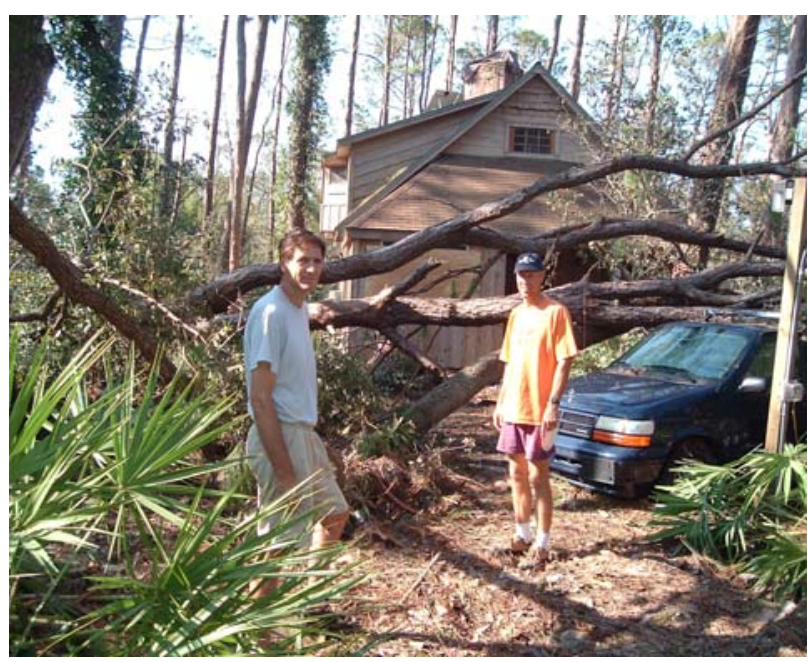

Fig. 4: Ivan at Ft. Walton Beach (PV).

\section{CONCLUSION}

People in the industrialized world are dependent on utility energy providers to meet energy needs. The importance of electricity is temporarily highlighted with any type of power outage, whether caused by a natural or manmade disaster or a minor weather-related event. There are options to improve energy security, such as energy efficient practices, distributing energy sources and using renewable resources. Ideally, creating zero energy homes and buildings would ensure a high level of energy security. Making modifications to homes and buildings by incorporating even minimal changes, such as the addition of a small photovoltaic array, would enhance energy security and yield long-term financial and environmental benefits. Studies and experience have shown that PV plays an important role in response, recovery and mitigation in disasters.

Because disasters can happen at any time with little or no warning, disaster resistant buildings and communities should be implemented. A true disaster-resistant building is structurally safe, functional and operational. Energy efficient buildings with fortified structural designs that use renewable energy systems attempt to mitigate the destructive forces of any disaster. This building method may cost more at the time of construction, but delivers priceless life and property saving after a disaster. Creating disaster-resistant buildings would reduce impact on shelters, emotional stress and recovery costs. 
There is a need to understand and apply disaster-resistant and fault tolerant architectural concepts in equipment, buildings and communities to reduce losses and improve quality of life. The need for power and the priority for those needs during disasters should be understood for effective use of renewables. Utility-interactive PV systems with battery backup increase the effectiveness of disasterresistant buildings and ultimately support communities in the power mix for distributed generation. It is the responsibility of each citizen to become aware of energy security issues and to accept a level of accountability for meeting personal energy needs.

\section{REFERENCES}

(1) Young, Jr, William, Photovoltaic Applications for Disaster Relief, FSEC-CR-849-95, Florida Solar Energy Center, Cocoa, FL, USA, March. 2001.

(2) A World Safe from Natural Disasters, The Journey of Latin American and the Caribbean, Pam American Health Organization, World Health Organization, Washington. D.C., USA, 1994.
(3) Young, Jr. William, History of Applying Photovoltaics to Disaster Relief, FSEC-CR-934-97, Florida Solar Energy Center, Cocoa, Fl, USA, Jan 1997.

(4) Young, Jr. William, Ventre, Gerard, and Thomas, Micheal, Needs Assessment for Applying Photovoltaics to Disaster Relief, FSEC-CR-935-97, Florida Solar Energy Center, Fl, USA, July, 1997.

(5) Hoff, T.E., C. Herig, and L. Gellettee, Distributed PV's Contribution to American's Energy Security: Tax Revenue Protection for the Federal Government, Interim NREL Report, 2002

(6) Becker, William, R. Stauffer, Rebuilding for the Future: A Guide to Sustainable Redevelopment for DisasterAffected Communities, U.S. Department of Energy, September 1994

(7) Deering, Ann, John, Thornton, Solar Solutions for Natural Disasters, Risk Management, February 2000

(8) Young, Jr. William, Photovoltaics: Disaster and Energy Security Applications, World Renewable Energy Congress VIII, Denver, Colorado, FSEC-PF-373-03, Florida Solar Energy Center, August 2004 